\title{
CYP2C19 Substrate
}

National Cancer Institute

\section{Source}

National Cancer Institute. CYP2C19 Substrate. NCI Thesaurus. Code C120267.

Any substance acted upon by cytochrome P450 2C19. 